\title{
Article
}

\section{Toward a Post-Apocalyptic Rule of Law}

\author{
Jeffrey Benjamin Meyers
}

check for updates

Citation: Meyers, Jeffrey Benjamin. 2021. Toward a Post-Apocalyptic Rule of Law. Laws 10: 65. https:// doi.org/10.3390/laws10030065

Received: 14 April 2021

Accepted: 11 August 2021

Published: 16 August 2021

Publisher's Note: MDPI stays neutral with regard to jurisdictional claims in published maps and institutional affiliations.

Copyright: (c) 2021 by the author. Licensee MDPI, Basel, Switzerland. This article is an open access article distributed under the terms and conditions of the Creative Commons Attribution (CC BY) license (https:/ / creativecommons.org/licenses/by/ $4.0 /)$.

\footnotetext{
(McLuhan 1970).
}

2 (Postmen 1992).

3 (Ibid., p. 73). Postman uses the term "information chaos" and it is used interchangeably herein with "information overload". See Footnote 4 below.

Keywords: law and literature; legal theory; intellectual history; conceptual philosophy

“The outer world has surpassed science fiction." (McLuhan 1970, p. 132) ${ }^{1}$

"Information has become a form of garbage, not only incapable of answering the most fundamental human questions but barely useful in providing coherent direction to the solution of even mundane problems." (Postmen 1992) ${ }^{2}$

\section{Introduction}

Declining political stability as well as pandemic disease and climate change have profound effects on individual and collective minds and bodies as much as they do on our shared imaginative and symbolic world. The same can be said of structural racism, consumptive capitalism, and colonialism. These are lived material realities, to one degree or another. The tendency to avoid acknowledging this and changing everything, might be attributable to what Neil Postman called "information chaos". ${ }^{3}$ Information chaos could explain why some voters chose Trump over Clinton or Biden, some citizens refuse a life-saving vaccine or deny the link between cars and climate change. Information chaos,
Faculty of Law, Thompson Rivers University, Kamloops, BC V2C 0C8, Canada; jmeyers@tru.ca

\begin{abstract}
This paper considers how science fiction, and the subgenres of speculative historicism and futurism in particular, might open legal discourse to hitherto unseen and potentially instructive perspectives. It begins with the proposition that recent historical events of global significance such as the election of Donald Trump in 2016, the outbreak of the Covid19 pandemic of 2020, and the extreme weather events of 2021, were widely predicted and foreseen in the media by way of political reporting as much as popular social and natural science reporting in the years and decades prior. The same tropes were also present in the plotlines of popular literature, television, and film during that period. The central argument of the paper is that before media pundits and policy-makers expressed their surprise at the fragility of the Rule of Law in the "unprecedented" ascent of Trump, the lethal capacity and transmissibility of a "novel" coronavirus, and the "sudden" arrival of climate change in the daily lives of North Americans and Europeans, the spectre of these menaces had already penetrated our collective conscious in a way that ought to have changed outcomes. Neil Postman's conceptualization of the present epoch as "Technopoly" is a means of explaining how, despite ample warnings, we were not ready for much. Technopoly refers to the historical present as the historical moment in which the technocratic capacity of individuals, states, and markets to respond to existential problems is hindered by information overload, e.g., the threat to the Rule of Law presented by an outgoing American President who refuses to accept the verdict of the electorate; the threat to public health posed by persistent vaccine misinformation and inequitable global vaccine distribution; and, the threat posed to our collective habitat by extreme climate events. The paper concludes that fiction is a powerful potential antidote to the numbing effects of information overload in Technopoly if it is treated seriously as a source of normative authority rather than dismissed as pure diversion.
\end{abstract}


like the related concept of "information overload", ${ }^{4}$ makes it difficult to see or remember patterns sufficiently long enough to address them as manifestations of larger or deeper problems.

When a country like the US struggles with the peaceful transition of power, the rollout of a vaccine, or acting to arrest climate change, it raises big questions about technocratic competence. The same for more mundane or outlying events like a renegade group of Reddit users who suddenly turn the stock market upside down. These types of systemic failures, large and small, seem resistant to control by the existing structures of the state and the market. Today, the fact that we can frame all of these problems as existential ones faced by the human species is some evidence, we are citizens of what Marshall McLuhan styled the global village.

Postman, whose books are more traditional and scholarly in their presentation than McLuhan's, describes the present as the age of "Technopoly". Postman's concept of Technopoly is introduced in the first part of this paper, ${ }^{5}$ which acts as an extended definition, framing and explanation of the concept from a legal perspective. Briefly, Technopoly describes the present mode of production in advanced or neoliberal capitalism in which "the judgment of individual workers" is "replaced by laws, rules, and principles of the 'science' of their job". This tendency derives, according to Postman, from the doxa at the heart of Technopoly, i.e., "that technique of any kind can do our thinking for us". 6 Process over substance. Form over content. In the language of jurisprudence, legal formalism over natural justice.

This paper employs a law and literature lens to consider what contemporary culture might have to say about apparently multiple simultaneous "existential" crises articulable at the global scale. Of particular interest to lawyers qua jurists, is any imagined or real crisis of the Rule of Law itself. A subject of research which has been the topic of robust scholarly attention in in the Anglo-American world and which tracks anxiety surrounding rising right-wing populism, Trump's ascent in the US and the UK's break with Europe in Brexit. That literature examines how forms of "populist democracy" and its insistences on political autonomy over judicial review can verge into authoritarianism and threaten the Rule of Law. ${ }^{7}$ This paper is written adjacent to this literature but borrows more extensively from media and literary theory, to consider how Postman's concept of Technopoly might address lingering concerns about whether contemporary forms of authoritarianism, can be contained or resolved by the Rule of Law. Any crisis of the Rule of Law presented by authoritarian populisms featured in this paper alongside other forms of rationality in crisis including the scientific and medical rationalities required to address pandemic disease and climate change.

To avoid unnecessary controversy around the definition of the Rule of Law however, it should suffice to define the concept provisionally in its thinnest and least controversial sense. Namely, that the Rule of Law binds sovereign and citizen alike, i.e., formal equality. A richer substantive iteration of the Rule of Law is of course also possible. However, none is required for the argument in this paper to proceed. Just as the deadliness of Covid19 and climate change are facts which are plainly observable and scientifically verifiable, the Rule of Law in crisis can be understood, although there is no universal consensus

4 The phrase "information overload" has been used by a variety of authors to mean a variety of related ideas, all of which relate to the quantity of available information in our culture, and the difficulty or impossibility of rationally processing that information and applying or acting on it meaningfully. Most of the key works have come from the fields of management and behaviourism. For the coinage of the term see (Gross 1964; Toffler [1970] 1971). For more recent usages see (Speier et al. 1999; Blaire 2011; Horrigan 2016; Lincoln 2011; Roetzel 2019). From the perspective of popular politics, conspiracy theories and the Trump era see (Rauch 2021).

5 See Section 1.1 below.

6 Postman, Footnote 2 above at 51.

7 In the US see (Driesen 2019; Rubenstein 2018). In Canada see (Watson 2015a, 2015b). In the UK and the EU see (Florea and Gales 2020; Kertesz 2016). For my own perspective, see (Meyers 2021). 
on measurement, in empirical terms. ${ }^{8}$ However, to avoid overly generalized usage of the phrase, this paper rigorously links its usage to specific examples, most from Trump era America. ${ }^{9}$

Adjacently, this paper is premised on the idea, that in the context of Technopoly, cultural content might better flesh out what is occurring than more familiar sources of legal authority such as case law, doctrine, or analytic jurisprudence. ${ }^{10}$ Specifically, fiction may be needed, because it lacks the dampening effects necessitated by legal formalism or academic convention in which truth discourses are mediated for the sake of their technocratic efficiency as much as their symbolic or representational qualities. This freeing effect recommends art and cultural content, or a humanities-based approach to law. Although such an approach is minoritarian, it need not be at odds with the methods or objectives of more established forms of legal scholarship. Such a refreshed approach may now be necessitated more than ever because the human mind suffers from an array of unconscious biases or collective psychic blind spots which tend to undermine objectivity and render neutrality aspirational more than real, particularly in the context of the information chaos or overload which is a characteristic of Technopoly. ${ }^{11}$ This paper therefore makes an unusual argument to break through the din. Namely, that we might read literature to remind ourselves of the fundamental questions which matter to us as citizens and stakeholders in a collective social and political project or contract. ${ }^{12}$ That said, no one is giving up on the efforts of lawyers in the trenches.

Speculative science fiction writer Kim Stanley Robinson describes the wrangling over sentences in environmental and climate change laws and treaties negotiated by committed lawyers and activists as imperfect but necessary and even heroic work:

The world runs by law and treaties, or so it sometimes seems; so, one can hope; the granite of the careening world held in gossamer nets. And if one were to argue that the world actually run by way of guns in your face, as Mao so trenchantly pointed out, still, the guns often get aimed by way of laws and treaties. If you give up on sentences you end up in a world of gangsters and thieves and naked force hauled into the street at night to be clubbed or shot or jailed. ${ }^{13}$

Robinson is not far off the traditional case for the Rule of Law as a rationalistic and pragmatic gloss of the status quo. He clearly recognizes the balance between justice and coercion which the law self-consciously strives to strike when it is at its best-and blows past when it is at its worst. Several pages later in an exchange between characters about the language of the "global village" itself and its usefulness in the near future when the world is faced with manifest catastrophic climate change, something more ambivalent emerges. In the relevant passage Robinson's protagonist, uses the concept of the global village to describe the potential for the emergence of a "global civilization transcending local differences" and is corrected in this universalizing instinct by her interlocutor: "Not really a village. Planetary consciousness, biospheric governance, citizen of Gaia, One Planet,

\footnotetext{
8 Although empirical evidence of global declines in the Rule of Law can of course be disputed, there is significant data backing the observation. To the extent such things are measurable in the same way as natural science data about atmospheric pollution and changes in ocean or air temperature, Freedom House reports 15 years of decline in all regions across the world in 7 categories: electoral process, political pluralism and participation, functioning of government, freedom of expression and belief, associational and organizational rights, the rule of law, and personal autonomy and individual rights. See (Bussey and Buyon 2021, p. 16); see also (World Justice Project 2020a), see e.g., (World Justice Project 2020b); Human Rights Watch World Report 2021 (at 7 in the preface, written by Executive Director, Kenneth Roth, the report itself is framed as a reflection of rising "autocratic tendencies" at the global level). See Contra (Versteeg and Ginsburg 2017) for the argument that most purported empirical or quantitative studies of decline in the Rule of Law are really more narrowly capturing indicators about the "impartial administration of justice" which is of course a part of what is understood by the Rule of Law but reflects a thin and formal understanding inadequately attuned to the thick and substantive understanding of the concept, inclusive of its normative commitments to liberal democracy counterbalanced by the protection of minority rights, etc.

9 See Section 1.1 below.

10 See Section 1.2 below.

11 These include various forms of unconscious bias and cognitive short circuits, which the social and behaviour sciences continue to uncover around things like risk perception and the personal level as well as more broadly at the social, communal, or even species level. See e.g., (Javanbakht and Capotescu 2020; Allen and Marco 2020; Slovic 2000; Slovic and Peters 2006). See more recently (Kunreuther and Slovic 2021).

12 See Section 1.3 below.

13 (Robinson 2020).
} 
Mother Earth, etc. More like that. Village is not really the right word."14 What is glimpsed here is the emergence not only of a global consciousness capable of understanding itself collectively as a "village", but of a village capable of contesting its own conceptual rubric to meet the moment.

Science fiction, the subgenres of speculative historicism and futurism in particular, are admittedly an unconventional means by which to open up established discourses, including legal and political ones, to new perspectives. Acknowledging some skepticism, the broader impetus for the paper is then not only the sense that we ought to have foreseen the Covid19 pandemic coming on the basis of widely available public reporting. ${ }^{15}$ It is also not simply that we ought to have foreseen the demagoguery of the Trump era on the basis of broader socio-legal tendencies in the preceding decades or that extreme weather events of recent years were repeatedly predicted by scientists. Instead, it is the sense that we are still not self-correcting off this path and that literature might provide a glimpse of what things will look like if we do not.

Rather than a linear or chronological approach to historical time, this paper argues that what is to come is manifest in the present. Similarly, it argues that the future is latent in the present, as is the excrescence of the past. Skepticism of experts, elites, and other oracles of knowledge is the affective valence of contemporary populism and it speaks to this complex dynamic. The very same skepticism is the link between problems as diverse as threats to the Rule of Law presented by authoritarian leaders, threats to public health posed by vaccine denial or threats to the planet posed by anthropogenic climate change. ${ }^{16}$ Underlying this paper is the hope that science fiction can provide some insights into the present situation which might otherwise be invisible to lawyers or policy-makers.

This paper takes seriously the possibility that there may be a cognitive limit on our collective ability to perceive risks at the species and planetary level in the same way we perceive risks to ourselves and our bodies in a more direct and immediate sense. ${ }^{17}$ This may be the way in which neoliberal individualism conditions us to imagine ourselves and interpret the world as subjects more than any innate or evolved condition. Either way, having regard to this powerful limitation, the departure point of this paper is that the present iteration of the global village is not the end of history but only an invitation to constant reinventing, rewriting, and revising of the present and its possible futures. ${ }^{18}$

The prognosis for the advancement of the Rule of Law, the control of the current and future global pandemics or the arrestation of catastrophic climate change, are not good. None of this should be controversial from a quantitative or empirical perspective. Ironically however, we are suffering from paralyzing information overload on these very topics! Breaking out of this paralysis is an objective of this paper. To make this break, a law and literature methodology is adopted.

Law, Common Law in particular, and literature as fields of inquiry have much in common. Both rely on narrative to compel story-telling, convey meaning, and lay claim to authority. Narrative, as storytelling, is also something which binds cultures and ratio-

14 (Ibid., p. 358).

15 See e.g., (Quammen 2012; Sha 2016; Osterholm and Oshaker 2017; Honigsbaum 2019).

16 At the intersection of affect and politics see (Durnová 2019). From a popular sociological perspective see (Jacoby 2009) tracing out the deep sociological roots of social Darwinism and pseudo-science in America's history and how that relates to the treatment of unequally valid ideas and theories as equally valid in the public and popular imagining. In a similar vein but with a greater emphasis on the role of technology see (Nichols 2018).

17 See Footnote 11 above.

18 (Fukuyama [1992] 2006). See Contra (Vattimo [1985] 1988, vol. 5-distinguishing between postmodernity as the end of history in the disastrous or dystopic sense from a more nuanced understanding in the context of a nuclearized world that the possibility of "atomic catastrophe" might permit us to finally understand that "the idea of history as a unitary process is rapidly dissolving"). 
nalities across time and space. ${ }^{19}$ However, few things, including understandings of what constitutes a legally culpable homicide or what rights are fundamental and which are socially constructed, can be agreed upon by common lawyers, let alone all jurists universally and at all times. ${ }^{20}$ This is what makes it very difficult to speak about something as abstract and aspirational as the Rule of Law in a way which satisfies the rigors of an analytic science. It is less controversial however to say that all human beings enjoy the innate capacity to imagine and evoke their own stories through language, art, and other forms of representation. Narrative requires intersubjectivity, sociality, and collectivity above individualism, isolation, and atomism. Modernity with its invention of the state which has naturalized the social contract and its imagining of human individuality, citizenship, and sovereignty create a hegemonic narrative which can become stifling. ${ }^{21}$ We can and should denaturalize it. $^{22}$ Literature might assist.

To question the reflexive, received, or established views of what constitutes a valid source of authority for diagnosing the legal, political, and technocratic challenges of the moment, this paper begins from the simple proposition that the present, with its manifest failure to prevent or adequately prepare for a predictable medico-scientific threat, pandemic zoonotic disease ${ }^{23}$ is precisely such a moment. Against this backdrop, the equally manifest and ongoing failure of humanity to constrain the destructive power of the nuclear bomb, ${ }^{24}$ an accelerating climate crisis, ${ }^{25}$ and a variety of other ills, including and relatedly, a decline in the Rule of Law in the leading countries of the West and elsewhere, ${ }^{26}$ propel a drive for some new way of seeing things and potentially acting on them. Consider the commonplace, yet at the same time sinister, utterances of popular politics in Trump's America expressed in slogans like "Make American Great Again", "very fine people on both sides", "all lives matter", etc. Alain Badiou describes this type of language as symptom "democratic fascism". ${ }^{27}$ Democratic fascism now corresponds with Technopoly. For relief from the news cycle which is sometimes itself overwhelmed by reactionary sloganeering of this sort,

19 This is the essence of Ronald Dworkin's imagining of the Herculean judge or the idea of the common law judgment as a chapter in a chain novel "working itself pure". For a forceful critique of the teleological aspects of this theory of adjudication see (Hutchinson 2005, pp. 71, 86). For a discussion of the role and value of narrative and storytelling to answering the fundamental question of what the law is at the intersection of Indigenous and non-Indigenous legal traditions in Canada, see (Borrows 2010), see e.g., at 118: "In order to have the common law, civil law, and Indigenous law work together in more harmonious ways, we will have to find better words, phrases, and frameworks to acknowledge and facilitate their coexistence"

20 Some modern natural lawyers have attempted to lay out such decisive list of human goods, see e.g., (Finnis [1980] 2011) (who stipulates the universal values of life, knowledge, play, aesthetic experience, sociability, practical reasonableness and religion). Some liberal political philosophers have attempted to do the same, see e.g., (Nussbaum 2000) (arguing that for a theory of social ordering to be just it must do certain things, e.g., recognize need of all human beings for food, shelter, and other basic resources for survival, give an account of procedures through which existing rules, laws, and norms can be changed, etc.). Among those writing on the Rule of Law there have also been attempts to set down such lists, see e.g., (Bingham [2010] 2011) (distilling the Rule of Law into foundational rules, e.g., The law must be accessible and intelligible; questions of right and liability should be determined by the application of the law and not the exercise of discretion, the law should apply equally to all unless objective differences justify differentiation, etc.).

21 (Harrari 2014, pp. 120, 171, 359). See also (Diamond [1997] 1999, pp. 283, 289). In a more specifically legal and political register see my comment (Meyers 2008) treating the literature on the Treaty of Westphalia and the system of states which continues to dominate the planetary legal order today.

22 This can and should correspond to a critique of the integration/accommodation binary which continues to dominate constitutional design debates. See (Meyers 2010).

23 See Footnote 15 above, widely available popular scientific literature warning of inevitability of global pandemic and consequences thereof.

24 While the UN continues to report lower numbers of nuclear weapons, today's forces are vastly more capable and instead of planning for nuclear disarmament, the nuclear-armed states appear to plan to retain large arsenals for the indefinite future. See (Kristensen and Korda 2020) "Disarmament Resolutions and Decisions of the Seventy-fourth Session of the United Nations General Assembly" in (UN 2019a). In a more philosophical register see Vattimo, Footnote 18 above at 5 (distinguishing between postmodernity as the end of history in the disastrous or dystopic sense from a more nuanced understanding in the context of a nuclearized world that the possibility of "atomic catastrophe" might permit us to finally understand that "the idea of history as a unitary process is rapidly dissolving"). For a palpably realist, well researched and executed imagining of a near future exchange of so called "tactical" nuclear weapons between the US and China see (Ackerman and Stavridis 2021) as discussed below in Section 1.2 below.

25 (UN 2019b). In her book on the way that the climate emergency has altered culture and consciousness, Sally Gillespie describes the psychology behind the existential threat that climate change poses (Gillespie 2019).

26 See footnotes $7-8$ above.

27 (Badiou 2019). 
one is well advised to read fiction. But one is equally well advised to read fiction for some insights into the nature and quality of contemporary Technopoly.

This paper is divided into three parts which broadly consider how speculative, often post or pre apocalyptic, science fiction can be expressed as an immanent critique of the present as Technopoly. This analysis is interdisciplinary and pluralist in the sense that it draws on social and cultural theory at the intersection of law, media, and literary studies. Part I ("The Legal Question") considers how speculative science fiction and alternative histories as subgenres thereof can speak to questions of relevance to lawyers and policymakers in Technopoly. Part II ("Literature as Primary Source") considers what it might mean to read literature and other forms of fictional narrative as sources of legal authority. Finally, Part III ("Re-Examining the Rule of Law for the 21st Century Media Ecosystem") briefly and experimentally introduces the concepts of biopolitics, affectivity, and cultism as potential avenues for further research.

\subsection{The Legal Question}

Understanding the role of law in society, like having an ideological and conceptual understanding of the Rule of Law and its contemporary status, ${ }^{28}$ necessitates an understanding of the nature of law's imbrication with communicative media. Adjacent to this, there are other related questions which have to do with the nature of technology and the relationship of human beings to it. Perhaps more foundationally however, law is itself a creature of language and representation. Language itself is a technology through which human beings intervene in their cognitive environment to represent, constitute, and contest. Language and usage as species of technology is the lawyers' vocation.

For lawyers, speech, writing, and now electronic media inclusive of a vast array of video and other digital images, are instruments of the trade. But they are also more than that, they are the immersive psycho-social media ecosystem in which law is interpolated. They are the habitus in which lawyers and policy-makers live and work. To understand what we are doing when we formulate legal arguments, draft legislation, or interpret case law, we must first consider the technological medium through which we express our interpretive efforts. At minimum, this is true if we are to take seriously McLuhan's famous injunction that the medium is the message.

\subsubsection{Methodology}

Inspired by what Peter Goodrich calls "jurisliterature" or "an attempt to insert the literary into the legal", 29 is a methodology which is self-consciously "contestatory of a major argot or discursive formation" in legal research, writing, and practice. It is an explicit challenge to the "the complacency and the claim to dominance and control that the major jurisprudence, the analytic, positivistic, literalist and frequently boring enterprise of legal closure likes to claim." Instead, it is a "minor" or minoritarian jurisprudence which seeks alternative perspectives and sources authority from outside the traditional disciplinary boundaries of the law and even sometimes its adjacent disciplines in politics and governance. ${ }^{30}$

Goodrich writes, "[t]he jursliterary embraces the interdisciplinary and its contemporary focus upon trans discourses seeks constantly to facilitate and relay experiences that underlie minor jurisprudences, the excluded languages, hidden figures, denied materiality and cultural forms that inscribe the returning peripheries of law's imperials gaze." ${ }^{31}$ To shake off that persistent imperial gaze it is necessary to explain how it took hold so powerfully in the first place. Conceptual philosophy is one way to do this.

The conceptual philosophy of the sort imagined by Gilles Deleuze and Felix Guattari is manifest in the indeterminate and productive capacities of binaries and dialectics of all

28 In the context of qualitative case studies drawn from the Canada, the US and the UK, see Footnote 7 above.

29 (Goodrich 2021, p. 45).

30 (Ibid., p. 46).

31 (Ibid., p. 111). 
sorts. In What is Philosophy, they write that "every concept relates back to other concepts, not only in its history but in its becoming or its present connections". ${ }^{32}$ Then later, "we are constantly trapped between alternative propositions and do not see that the concept has already passed into the excluded middle ... "33 In the case of the Rule of Law, the dialectical tension between law as judicial review alongside constitutional supremacy on the one hand, and politics as democratic elections alongside legislative supremacy on the other, is itself irresolvable.

Mr. Trump was ultimately the only US President to be impeached twice and acquitted twice. At the time of writing, Democrats in Congress have not yet found a way to exclude him from running for a second non-consecutive term. ${ }^{34}$ Trump's return to office in 2024 is therefore possible future outcome which is formally permitted by the US Constitution. ${ }^{35}$ Fundamentally, Trump's ouster from office by the electorate in 2016 still does not fix the problem he represents or the underlying conceptual crisis of the Rule of Law that his presidency, not unlike the Brexit vote in the UK and other similar types of populist politics elsewhere represent. ${ }^{36}$ Over the past several years, the neoliberal globalism and internationalism of the first decade of the twenty-first century has accommodated itself to an apparent populist conservative backlash insistent on authoritarian nationalism and far right conspiracies. This might be about fractured brand loyalty as much as it is about ideological politics. What is Trumpian politics if not the lifestyle brand of MAGA? What is Brexit if not a symbolic insistence on the British over European identity in the world?

Neil Postman was remarkably prescient about what was to come, even in the years immediately prior to the world-changing effects of the Internet. He foresaw the corporatization of politics and the hybridization of entertainment in the cable news era of the nineties as part of an emergent global media ecosystem which differed from the earlier age of more conventional television. He saw that financial capital, entertainment, and politics were converging in the public imagination at an alarming rate at the end of the twentieth century. Writing in 1992, nearly a decade before the Internet would become what it was and several decades before Donald Trump would become President of the United states, Postman speculated about a dystopic future in which the United States demonstrates that it is no longer a culture but simply an economy, ${ }^{37}$ i.e., America Inc., the product and the brand. Presciently if not prophetically, Postman asks, "How many would applaud this mission? Indeed, who could we use to speak such words—Barbara Bush? Lee Iacocca? Donald Trump?"38

The corporatization and privatization of the state, at the level of the global village and the transformation of the civic discourse into the cable news cycle of the nineties was the media ecosystem from which the great innovations of the next century would spring. The Internet, the invention of smart devices, and eventually social media all grew out of the firmament which Postman described as Technopoly. Because the human mind suffers from a variety of unconscious biases or collective psychic blind spots which may make a sound appraisal of the current moment more rather than less difficult, ${ }^{39}$ there is some need to go beyond the usual way of diagnosing matters.

Still, why look to fiction or literature rather than social science data, statutory authority, case law, international treaties, or some other source of positive law? One reason is that vague appeals to the Rule of Law through a renewal of our legal institutions or reform of our political, administrative, and state-based institutions, have struggled to respond to the

(Deleuze and Guattari [1991] 2003, p. 19).

33 Deleuze and Guattari (ibid., p. 22).

34 There are two ways to do this pursuant to the US Constitution. The first is by a simple majority of the Senate after a conviction at trial for impeachable offences, this obviously did not happen on the two occasions it was attempted. The other is a more obscure approach which has not been tried, see Amendment XIV §3. See also (Trautman 2019, p. 529).

35 United States Constitution, Amendment XXII § 1.

36 See Meyers, J. "What We Talk About When We Talk About the Rule of Law" Footnote 7 above.

7 Postman Footnote 2 above at 175.

Ibid.

39 See Footnote 11 above. 
factual reality of the present moment using established appeals to reason and science. The widely felt crisis of the Rule of Law presented by the Trump presidency or the conditions surrounding Brexit in the UK are tough to fully explain using the usual conceptual toolbox available to western liberal democracies. ${ }^{40}$ The same can be said of vaccine hesitancy and climate denialism. To make the case for why lawyers should diversify our sources of inspiration, learning, and authority to include fictional literature, television, and other sources of cultural content, high and low, Neil Postman's understanding of the transition from Technocracy to Technopoly is essential.

\subsubsection{Intellectual History: From Technocracy to Technopoly}

Technocracy, Postman explains, was borne of the great innovations, technical and conceptual, of the late eighteen century that coincided historically with the bourgeois revolutions in France and America. The key technologies that emerged in the early stages of Technocracy were as much mechanical like the steam engine as they were ideological like free market capitalism. They were corporeal or material structures as much as they were ideological or ideational ones. In the next stage of Technocracy which Postman describes taking shape in the nineteenth century, new innovations tended to be in communication technology, such as the photograph, telegraph, typewriter, transatlantic cables, and eventually the telephone and radio. These emergent technologies shrunk time and space and had profound effects on the affective environment of an emerging global village. Although the mature iteration of McLuhan's global village is contemporaneous with the transition to Technopoly at the close of the twentieth century, its earliest stirrings went back centuries to the invention of the printing press at the opening of the modern. This was the subject of McLuhan's inquiry in The Gutenberg Galaxy. ${ }^{41}$ Postman's argument is that change accelerated in the late nineteenth and early twentieth centuries such that the delicate truce between modern and traditional worldviews arrived at by prior generations were reaching a point of crisis. Technocracy's spectacular failure was felt most obviously, Postman wrote, at mid-century in the two world wars. ${ }^{42}$

To make sense of all of this, it is important to understand just what Technocracy was and how the transition to Technopoly began. According to Postman, the first flash of Technopoly itself emerges over a century ago in the passage from the nineteenth to the twentieth century as science and technical reason become increasingly restless in their uneasy truce with tradition and commonly held beliefs. Crucially, Postman explains how the literature of the period, like the legal and political writings of the time, spoke to this tension. In Aldus Huxley's 1932 novel Brave New World, the technological completely subsumes the traditional offering a first glimpse of the transition from modern Technocracy to postmodern Technopoly. A similar method of exposition, relying on science fiction as a source, follows in Part II below. For the moment however, Postman states it thus,

[T]wo opposing world-views - the technological and the traditional-coexisted in uneasy tension. The technological was the stronger, of course, but the tradition was there-still functional, still exerting influence, still too much alive to ignore. This is what we find documented not only in Mark Twain but in the poetry of Walt Whitman, the speeches of Abraham Lincoln, the prose of Thoreau, the philosophy of Emerson, the novels of Hawthorne and Melville, and, most vividly of all, in Alexis de Tocqueville's monumental Democracy in America. In a word, two distinct thought-worlds were rubbing against each other in nineteenth-century America ... With the rise of Technopoly, one of those thought-words disappears. Technopoly eliminates alternatives to itself in precisely the way Aldous Huxley outlined in Brave New World. It did not make them illegal. It does not make them immoral. It does not even make them unpopular. It makes them invisible

40 See Meyers, J. "What We Talk About When We Talk About the Rule of Law”, Footnote 7 above.

41 (McLuhan [1962] 2011).

42 Postman Footnote 2 above at 48. 
and therefore irrelevant. And it does so by redefining what we mean by religion, by art, by family, by politics, by history, by truth, by privacy, by intelligence, so that our definitions fit its new requirements. Technopoly, in other words, is totalitarian technocracy. ${ }^{43}$

In the pivot from the nineteenth to the twentieth century, Huxley, understood something like the shift to Technopoly to be tied to the form of production and labor itself. This explains why time in Brave New World is designated "BF" for "Before Ford" and "AF" for "After Ford." Postman's reading of Huxley also tied to Taylorism and the rise of expert or scientific management in late modernity. Crucially, Taylorism would re-imagine the management of different fields into the management of information in which everything must be measured and subject to calculation for efficiency. For lawyers and legal theorists this is expressed in the approach of law and economics. The emphasis then, both technical and ideational, is invariably on process, balanced against efficiency, rather than on substantive content or normative outcomes dictated by a coherent theory of justice. This renders all aspects of human conduct and human affairs calculable and subject to management theory. The early tendencies of Technopoly speak eerily to what would express itself as neoliberalism and globalized capitalism at the close of the twentieth century:

Taylor's book, the Principles of Scientific Management, published in 1911, contains the first explicit and formal outline of the assumptions of the thought-world of

Technopoly. These include the beliefs that the primary, if not the only, goal of human labor and thought is efficiency; that technical calculation is in all respects superior to human judgment; that in fact human judgment cannot be trusted, because it is plagued by laxity, ambiguity, and unnecessary complexity; that subjectivity is an obstacle to clear thinking; that what cannot be measured either does not exist or is of no value; and that the affairs of citizens are best guided and conducted by experts. ${ }^{44}$

This is the essential definition of Technopoly referenced in the introduction. It is worth reemphasizing. When Postman writes that the result of this ascendant worldview is that "the judgment of individual workers was replaced by laws, rules, and principles of the 'science' of their job", he is indeed describing our own world in which "technique of any kind can do our thinking for us". Lawyering or policy-making, for instance, are predictably coded as question of legal acumen or technique notionally distinct from moral or political rightness or desirability. Indeed, the two are often said to conflict. This is consistent not only with the language of legal formalism over legal realism, it is also consistent with the worldview of Technopoly.

In the language of jurisprudence, Technopoly is characterized by an insistence on legal scientism over natural or substantive justice because law itself is insistently limited to being a technique rather than a properly social or political intervention. In the earlier Technocracy, there remained memory or excrescence of justice. However, by the time of full blown Technopoly, the echo is increasingly faint. For Postman this goes even further back to Auguste Compte, whose philosophical positivism and sociological worldview presaged Technopoly by over a century. Postman similarly interprets Tocqueville's reading of American democracy as a prescient early glimpse of the American impulse to seek liberty and growth, to push beyond the frontier, first with the colonial project, and later with runaway growth and development. ${ }^{45}$ However, computerization changed everything, or at least supercharged it well before the advent of the Internet as it is currently understood. In 1992, Postman stated it thus,

43 Ibid.

44 (Ibid., p. 51).

45 Around the same time that Postman was writing, Antonio Negri made a similar argument (Negri [1992] 1999, pp. 153, 178-81, 242-47). 
Like the Sorcerer's Apprentice, we are awash in information. And all the sorcerer has left us is a broom. Information has become a form of garbage, not only incapable of answering the most fundamental human questions but barely useful in providing coherent direction to the solution of even mundane problems. To say it still another way: The milieu in which Technopoly flourishes is one in which the tie between information and human purpose has been severed, i.e., the information appears indiscriminately, directed at no one in particular, in enormous volume and at high speed, and disconnected from theory, meaning, or purpose ... All of this has called into being a new world. ${ }^{46}$

The argument that in Technopoly, information has become a form of garbage is more than provocative claim as cited in the epigraph, it is a descriptive claim of central importance. Technopoly for Postman, is a "state of culture" which consists primarily of the "deification of technology". The deification of technology means, according to Postman, an outsized belief or faith in technology to resolve problems and bring about progress. Not only is this a fantasy, Postman warns, it will lead us to confuse information with knowledge, data with meaning. In this regard, Postman was again deeply prescient.

Postman's critique of what was already in the early nineties, a rapidly consolidating information economy, can now be read against the backdrop of the contemporary ascension of Facebook, Google, Amazon, Apple, and other tech giants in the decades to follow. Today, the tech giants whose profits know no limits and whose power is only dimly appreciated by the governments who struggle to regulate them, rule us by algorithm. One can be forgiven for musing that had Twitter "de-platformed" Trump in 2015 instead of 2021, they might have saved us all the trouble. Writing in 1992, Postman foresaw the direction things would take in the next century:

Those who feel most comfortable in Technopoly are those who are convinced that technical progress is humanity's supreme achievement and the instrument by which our most profound dilemmas can be solved. They also believe that the information is an unmixed blessing, which through its continued and uncontrolled production and dissemination offers increased freedom, creativity, and peace of mind. The fact that information does none of these things-but quite the opposite-seems to change few opinions, for such unwavering beliefs are an inevitable product of the structure of Technopoly. ${ }^{47}$

This is prescient because in the context of the worship of technology as progress, western civilization, perhaps America and its influence in particular, has long been on this path. But Postman raises the question of information overload or information glut as a conundrum well before the world of Google searches and Facebook feeds and the hacked Presidential elections of the present. Yet, Postman even seems to anticipate the way in which information requires regulation to avoid becoming a chaotic dump of incoherent noise:

In particular, Technopoly flourishes when the defenses against information breakdown ... When the supply of information is no longer controllable, a general breakdown in psychic tranquility and social purpose occurs. Without defenses, people have no way of finding meaning in their experiences, lose their capacity to remember, and have difficulty imagining reasonable futures .... One way of defining Technopoly, then, is to say it is what happens to a society when the defenses against information glut have broken down. It is what happens when institutional life becomes inadequate to cope with too much information. It is what happens when a culture, overcome by information generated by technology, tries to employ technology itself as a means of providing clear direction and human purpose. The effort is mostly doomed to failure. Though it is sometimes

6 Postman Footnote 2 above at 69-70.

47 (Ibid., p. 71). 
possible to use a disease as a cure for itself, this occurs only when we are fully aware of the process by which disease is normally held in check. ${ }^{48}$

Several passages later, Postman outlines how people become vulnerable to "information chaos" 49 where institutions which would otherwise function as control mechanisms for interpreting, contesting, and vetting information, fail. Today we might be reminded of the information environment surrounding the 2016 and 2020 presidential elections in the US, the necessity of vaccination against Covid19 in 2021 or any number of other examples. Clearly, the social media and tech companies in Silicon Valley are different than the old technocratic corporations of prior American centuries insofar as they are "concerned with the meaning of information and can be quite rigorous in enforcing standards of admission." ${ }^{50}$ It took many years, but even Donald Trump eventually learned this.

\subsubsection{Rule of Law as the Destruction of Information?}

Of interest to lawyers and from a Rule of Law perspective, Postman uses the example of a courtroom and the rules of evidence. The purpose of the law of evidence, he notes is to greatly limit what is relevant and what is to be considered by a jury. This is what he means when he says "the Rule of Law is concerned with the 'destruction' of information." 51 This is similar to what Robert Cover described as the jurispathic quality of legal decision making. ${ }^{52}$ The reason for this, Postman suggests, is ideological insofar as it relates to a particular view of human liberty as most obviously expressed in the presumption of innocence in the criminal process and to the assessment of liability on the balance of probabilities for wrongdoing in a civil process. In this sense, Postman is clearly correct that the "the rules on which such control is based derive from a theory of justice that defines what information may be considered relevant and, especially, what information may be considered irrelevant." 53

The notion of the Rule of Law more broadly refers both to the rules of evidence which circumscribe what lawyers may introduce as evidence at trial, but also the authority of the courts to rule on inclusion or exclusion of evidence generally. Both derive from the basic principle of formal equality reflected in the baseline definition of the concept. With the advent of the Internet and especially of sophisticated common law case search algorithms, however, legal practice and legal research has been radically reshaped, not only by the availability of more and better sources of precedent, authority, and commentary, but by means of technological innovations in tracking, preserving, and cross-referencing data offered as evidence of legal liability. These tendencies not only raise the complexity of managing evidence for trials, but also relate to our capacity for meaningfully sorting through the volume of data available which is available to lawyers as much as policymakers generally. To date, the law has yet to fully adapt to the surveillance world this creates for litigation and evidentiary rules conceived in an analog age. ${ }^{54}$ Well before the Internet however, Postman grasped that the emergent information-based iteration of the global village would ultimately coincide with a crisis of the Rule of Law, not only at the macro level of world historical events, but at the most granular level of legal practice:

In even the simplest law case, thousands of events may have had a bearing on the dispute, and it well understood that, if they were all permitted entry, there could be no theory of due process, trial would have no end, law itself would be reduced to meaninglessness. In short, the Rule of Law is concerned with the 'destruction' of information. 55

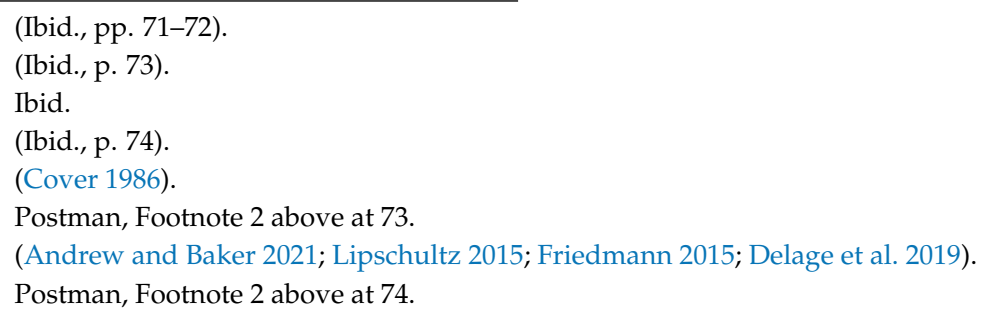


At first strange and provocative, the claim that law is concerned more with the destruction than with the preservation of information, has a rich intellectual history in western thought. At the close of the nineteenth century, Nietzsche's Zarathustra stands amid the destruction of legal tablets and states it thus, "Here I sit and wait, surrounded by broken old tablets and new tablets half covered with writing. When will my hour come?" ${ }^{26}$ For Zarathustra, destruction precipitated a moment of regrowth, reinvention, and resilience. Speaking specifically to the conundrum of law, a century after Zarathustra's joyful destruction, Postman writes,

[A]lthough legal theory has been taxed to the limit by new information from diverse sources-biology, psychology, and sociology, among them-the rules governing relevance have remained fairly stable. This may account for Americans over use of the courts as a means of finding coherence and stability. As other institutions become unusable as mechanisms for the control of wanton information, the courts stand as a final arbiter of truth. For how long, no one knows. ${ }^{57}$

Few would now say that courts truly stand, if they ever did, as final arbiters of truth. Courts generate context specific judgments which are subsequently debated, contested, revised and clarified in the endless cycle that is the Common Law. Occasionally courts will take judicial notice of major phenomena like climate change. ${ }^{58}$ Postman's point is nevertheless well taken indeed. The Rule of Law more broadly, when it is at its best, signifies a sort of rational process of sorting information based on its legal relevance as much as it does on the basic idea of substantive equal protection. Seen in this way, the Rule of Law is also similar to other forms of institutional rationality in Technopoly whose calculating and automated qualities often sort and define information faster than it can be processed in a meaningful way.

\subsubsection{Informational Virality: Vaccinating against Forms of Contagion Virtual and Real}

Postman was attentive, even in the years immediately preceding the advent of the Internet, to the way in which virality could now be understood as a question of software and electronic or digital corruption as much as one of public health or population medicine. He traced the language of the computer virus and the idea of information contagion very specifically to an incident in 1988 when the US military's Advanced Research Projects Agency Network (ARPANET) experienced a technical glitch in which networked computers across the world were infected. He goes on to describe how the language of viruses and infection went hand in hand with the transition to full-blown Technopoly:

As Raymond Gozzi, Jr., discovered in his analysis of how the mass media described the [1988] event, newspapers noted that the computers were 'infected,' that the virus was 'virulent' and 'contagious,' that attempts were made to 'quarantine' the infected computers, that attempts were also made to 'sterilize' the network, and that programmers hoped to develop a 'vaccine' so that computers could be 'inoculated' against new attack ... ${ }^{59}$

"This kind of language is not merely picturesque anthropomorphism", Postman tells us, "it reflects a profound shift in perception about the relationship of computers to humans. ${ }^{\prime 60}$ Not only was Postman prescient about the meaning and importance of computer viruses and the type of language given over to describing them, but he also grasps the underlying fear of contagion and infection which is part of every human being's embodied existence and a part of our natural life as a species. Viruses and virality are part

56 (Nietzsche 1892, 1977). See also (Goodrich and Valverde 2005; Meyers 2020).

57 Postman Footnote 2 above at 74.

58 In Reference re Greenhouse Gas Pollution Pricing Act, 2021 SCC 11 (Para 171), Chief Justice Wagner of the Supreme Court of Canada recognized climate change as an "existential threat to human life in Canada and around the world".

59 Postman Footnote 2 above at 113-14.

60 Ibid. 
of our informatic environment or media ecology as much as they are a part of our natural environment. Understood in this way, the Rule of Law might be, as Postman suggests, one bulwark against information glut. A dangerous glut which Postman attributes to the reification of information qua information.

\subsubsection{Contagion: Who Is the Virus and Who Is the Host?}

If we can readily imagine that the global village is today menaced by contagion, both virtual and real, from the perspective of geological time and the imagination of the present as the Anthropocene, ${ }^{61}$ it is even possible to argue that the human species might itself be the most virulent virus which infects the planet. Arguably, earth would be better off without us. Most academics, intellectuals, and university professors, myself included, worry about appearing or sounding alarmist because it goes against the liberal doxa that all matters of public relevance or debate are things about which polite disagreement is possible and about which some evidence can be marshalled for one side or the other.

In Technopoly, Anglo-American Constitutional Law, First Amendment rights in the US in particular continue to be addressed through the prism of the so called "market place of ideas". ${ }^{62}$ But, what if the gauzy imagining of the free marketplace of ideas in which the best supported, most evidence-based claims rise to the top and the least supported, most conspiracist or irrational, sink to the bottom, is falsified before our very eyes? What if the creaky old imagining of the marketplace of ideas and the free speech to which it is imagined to correspond is a fantasy rather than a reality? Scholars are beginning to probe these fraught questions. ${ }^{63}$ What is however clear now though, is that the line between information and speech will surely get more rather than less complex in the decades to come. Contrary to popular conjecture, artificial intelligence is also unlikely to solve, or make irrelevant, this type of higher order problem for human beings anytime soon. Thankfully, even algorithms, which are immensely powerful and even constitutive of our being in some ways, have limits. ${ }^{64}$ The problem of the free marketplace of ideas is not one which can be resolved by technology or defended conceptually in the context of information glut. This is the essential through line which links the diverse examples of contemporary crisis facing McLuhan's notional global village, from a declining global Rule of Law culture to pandemic disease to the manifest climate change which characterize the present moment of Technopoly.

\subsubsection{Information Glut and the Marketplace of Ideas: Normalizing the Unprecedented}

What Postman calls the "information glut", makes apparent that any imagined free marketplace of ideas in the late twentieth century, even prior to the advent of the Internet, was already more aspirational than real. In the context of information glut or overload, the imagined "marketplace of ideas", 65 if it ever existed, does not assist the untrained consumer of information to determine what is, and is not, reliable. One may of course be a more or less rigorous, or a more or less sophisticated, consumer of electronic media, just as one might have been better or worse at detecting editorial bias in the broadsheets of yore. But we no longer simply consume media, it now also consumes us in return. Or perhaps more precisely, we do not just consume media by reading it on the bus or at our dining room tables, we are constituted both individually and collectively as citizen subjects by the media ecosystem in which we reside as affective subjects within the global village. Our individual drives then, even our impulse toward solidarity is frequently given over through our usage of the electronic media, or perhaps really its usage of us rather than vice versa.

61 In her book on the way that the climate emergency has altered culture and consciousness, Sally Gillespie describes the psychological complexity behind the existential threat that climate change poses. See Gillespie Footnote 25 above. See also (Robinson 2014).

62 (Brown et al. 2011).

63 See e.g., (Napoli 2018).

64 See generally (Larson 2021).

65 See Brown, Rex, Herrera et al., Footnote 62 above. 
Under these circumstances, our environment then, is increasingly a virtual and affective one which exists to conduct information and to process it once it has already been refined through various algorithms for us. Perhaps we are increasingly overwhelmed by the information itself because our mammalian brains are not up to the task? ${ }^{66}$ Consider again the example of the Trump administration and the rapidity as much as the rabidity of scandals which emerged throughout his "unlikely" and "unexpected" candidacy in 2015. Consider also the impossibility, no matter the effort, of turning Trump's most fervent supporters against him during the general election campaign in 2016. Then consider Trump's ensuing norm destroying presidency and the 2020 re-election campaign in which he was finally defeated but nevertheless managed to turn out more voters than any other previously losing candidate and convince his supporters they were disenfranchised without a scintilla of evidence.

An astonishing variety of the Trump presidency's affronts to the Rule of Law were brazen and transparent, utterly public and carried live into the minds and eyes of the world, often in real time. Equally astonishing numbers of presidential utterances during his tenure were proven verifiable lies by fact-checkers the instant they were spoken or tweeted. Yet, despite the fact that armies of fact-checking journalists and researchers debunked much of what former President Trump said, typed, or insinuated, it was never quite enough to dislodge him from office until 2020. And then, just barely!

The assault on the Rule of Law embodied by the Trump presidency, became possible only within the context of the emerging twenty-first century media ecosystem in which the old marketplace of ideas decayed into a charade of its former self. At this stage, entertainment and authority were conflated in the consumption of what had hitherto been known as news or current events. This tendency was understood even before Postman had theorized Technopoly and speculated jokingly about Trump's political future in 1992, by Guy Dabord in 1967. Dabord styled it the "society of the spectacle". ${ }^{67}$ At the opening of his book of the same name, he writes, "In societies where modern conditions of production prevail, all life presents itself as an immense accumulation of spectacles. Everything that was directly lived has moved away into a representation." ${ }^{68}$ This echoes McLuhan's idea that the medium is the message insofar as the representation of the legal or the political is now the main show, and its relationship to reality or lived experience is secondary or in the shadows. It also corresponds to the idea of Technopoly as an epoch in which information overload or information glut prevents the marketplace of ideas from functioning coherently. It should of course then have come as no surprise that Trump's only real success before becoming President was as a reality tv star. Reality tv, itself an obscene bricolage of entertainment, performance and real striving (for adulation, prestige, money or any other egomaniacal needs) was the perfect training ground for Trump. It seemed his presidency was a seamless continuation of his personal brand as an entertainer, provocateur, grifter, and ultimately nothing else. ${ }^{69}$ Yet, it might also have been something more.

Toward the end of his presidency, Trump's continued failure to acknowledge the reality of a deadly public health pandemic may have diminished him sufficiently to lose his re-election bid. But his ascendance had from the beginning expressed a tendency already nascent in the transition from Technocracy to Technopoly. A tendency Postman described in terms of information glut and Dabord understood even earlier in the society of the spectacle. More recently, Badiou uses the language of "democratic fascism" to describe how this current epoch is both contiguous with, and distinguishable from, the earlier threats to the Rule of Law in the 1930s,

It is often said that these new [right-wing nationalist/populist authoritarian] political figures-Trump, to be sure, but many others in the world today-resemble

66 (Klingberg 2009). Also see generally Footnote 4 above.

67 (Debord [1967] 2010).

68 (Ibid., p. 1).

69 (Baker 2017). 
fascists of the 1930s. There is indeed a certain resemblance. But, alas, there is also a major difference: today's new political figures do not have to confront the powerful and intractable enemies that were the Soviet Union and the communist parties. In fact, we could speak of these new figures in terms of a kind of 'democratic fascism', a paradoxical but effective designation. After all, the Berlusconis, the Sarkozys, the Le Pens, the Trumps, are operating inside the democratic apparatus, with its elections, its oppositions, its scandals, etc. But with this apparatus, they are playing a different score, another music. This is certainly the case with Trump, who is a racist, a male chauvinist, violent-all of which are fascist tendencies-but who, in addition, displays a contempt for logic and rationality and a muffled hatred of intellectuals. The music proper to this type of democratic fascism is a discourse that does not worry in the least bit about coherence, a discourse of impulse, comfortable with a few nighttime tweets, and that imposes a sort of dislocation of language, positively flaunting its ability to say everything and its opposite. For these new political figures, the aim of language is no longer to explain anything or to defend a point of view in an articulate manner. Its aim is to produce affects, which are used to create a fleetingly powerful unity, largely artificial but capable of being exploited in the moment. $^{70}$

As stated in the introduction, "Make American Great Again", "very fine people on both sides", "All lives matter", these were some of the most memorable utterances of Trump's era and they are what Badiou describes using the language of democratic fascism. The convergence of Badiou's understanding of the present and Postman's grasp of the historical tendencies already in play decades earlier in the emergence of Technopoly is telling. Perhaps what defines this trajectory is that it is now difficult to resist false and manipulative narratives, even in the face of true and evidence-based alternatives. This is so not because conspiracy theories are inherently compelling but because they are treated as neutral information like all other information, as data points, or inputs, rather than as political utterances or statements with potential legal or institutional effects. Fictional literature and art are an untapped space for critique, reflection, and reinvention.

\subsection{Literature as Primary Source: Mining Literary and Pop Culture for Meaning}

There may be something to learn about the present reality of Technopoly as discussed in Part I above, and its relationship to the Rule of Law to be more fully addressed in Part III below, from the speculative social, political, and legal worlds of fictional literature, television and film here. With speculative fiction in particular, we can imagine a different past or an unknown future in all its utopian and dystopian possibilities. For those who read speculative fiction, it has been surreal to find the tropes we have been imagining in our moments of narrative reverie, suddenly manifest in our every-day lives and in world historical events. Examples abound, three fictional narratives popular in the years prior to the Trump presidency and the Covid19 pandemic are representative: Philip Roth's novel, The Plot Against America; ${ }^{71}$ Jo Nesbø and Erik Skjoldbjærg's Norwegian television drama, Occupied; ${ }^{72}$ and, Eric Larson's historical reconstruction of Berlin in the early years of the Third Reich, In the Garden of the Beast. ${ }^{73}$

Consider some books or niche tv programs which you may have consumed. Did you watch the Netflix blockbuster House of Cards and then lose interest when Trump became President and Kevin Spacey's own personal story as a celebrity eclipsed Frank Underwood's as a character? I did. The pleasure of watching the program disappeared the moment the villainy of the real and the simulacrum began to converge and swamp

70 Badiou, A. Footnotee 27 above at 13-14.

71 (Roth 2004).

72 Available online via Netflix.

73 (Larson 2011). 
our consciousness. Our media ecosystem is too often ignored in serious political and legal analysis, as is our choice of novels and our interest in what lies between their covers.

\subsubsection{What Is Stranger? Truth or Fiction?}

Philip Roth's counterfactual historical novel, The Plot Against America ${ }^{74}$ is premised on an imagined alternate history in which the aviator and pop icon Charles Lindbergh is the Republican Party presidential nominee in 1940 and beats FDR in the election on an isolationist "America First" platform which promises to keep the US out of "Europe's War". While written over a decade before Trump's actual ascent to the presidency, the resonance with Trump's America is powerful. The Plot Against America was published in 2004 and aired as an Amazon Prime mini-series early in the pandemic.

The second example is a Norwegian television series by writer Jo Nesbø and director Erik Skjoldbjærg entitled Occupied. Occupied evocatively imagines a near future in which Russia annexes Norway, it is now available on Netflix. Russia's real-world aggression in its near abroad and the growing bellicosity of Putin's foreign policy was clearly long part of Norway's collective cultural subconscious, the show has however been popular globally and speaks to a certain nervousness in the global village. ${ }^{75}$ It is worth noting in a similar vein, Elliot Ackerman and Admiral James Stavridis, near future thriller, $2034 .^{76}$ That book imagines a tactical nuclear war between American and China, with global dimensions including Russia and India. Underlying this chillingly realistic account, written by military insiders with considerable access, is the complexity of Russia and China's growing competence as peer militaries closing their capability gap with the US, particularly in the cyber realm.

2036, named after the imagined year upon which military hostilities breakout between the US and China in the South Pacific, is a reminder of the unique power of literature to direct the consciousness forward to potential risks. It resonates strongly with the affective environment produced in Occupied.

Finally, Eric Larson's historical account of prewar Berlin, In the Garden of the Beasts, ${ }^{77}$ looks to the reality of the historical past rather than to an imagined dystopic future to alert the reader to the risks of the present. Fictional narrative has the advantage of experimenting with temporality in this way and can therefore present nonlinear ideas in a way which sharply distinguishable from traditional legal narratives. Larson's account of prewar Berlin, which although written years before the election of Trump, like affective environment conjured in The Plot Against America, resonates strongly with the late Trump era where the specter of political extremism and pandemic disease combines to terrorize us all. Perhaps not surprisingly, Larson's book has since been adapted into a movie directed by Joe Wright and produced by Tom Hanks which will feature at the 2021 Sundance Film Festival. While the basic story and underlying sources are historical and less fictional than actual, the book's mood and valence, like the ones in The Plot Against America and Occupied, speak to the present. Each of these books or streaming television programs permit a unique angle of reflection of the nature of Technopoly and of the apparent crisis, among others, of the Rule of Law within it.

In Roth's counterfactual historical novel, the Plot Against America, the imagined President Lindbergh steers America out of World War II and enters into a détente with the Nazi Germany and Imperial Japan against the Allies and the Soviet Union. The relationship between the imagined President Lindbergh and the Hitler character is similar to the one we might reasonably imagine existed between President Trump and President Putin. In the book, again written well before the Trump presidency, Roth paints Lindbergh being manipulated into complacency and abandonment of America's traditional allies while Hitler expands his grip on Europe. The Plot Against America also considers what an America with

74 Roth, P. Footnote 71 above.

75 See Footnote 24 above re UN \& scientific reporting on nuclear weapons proliferation and disarmament efforts.

76 Elliot Ackerman \& Admiral James Stavridis Footnote 24 above.

77 Larson, Footnote 73 above. 
an officially antisemitic, xenophobic, and fascistic tendencies might have looked like in the forties. What emerges is uncannily reminiscent of Trump's America. In the novel, the father of the protagonist is an FDR supporter and resembles an Obama era liberal gobsmacked by the ascendency of Trump and his jettisoning of America's traditional allies for the open admiration of dictators and despots. Lindberg, the imagined Nazi sympathizing President and his authoritarianism continually catches Roth's protagonist by surprise: "But my father could see nothing. 'You think you'd hear that here if Roosevelt was president? People, wouldn't dare, they wouldn't dream, in Roosevelt's day ... It's disgraceful. It starts with the White House ... '"'78

In the alternative history of Roth's novel, America's own Anti-Semitism and nationalism conquered its better angels and Roosevelt was defeated by someone who could not tell the difference between Hitler and Churchill. In the Trump years it was clear that NATO allies in the western alliance were of less interest to Trump than despots like Putin, $\mathrm{Xi}$, and other traditional American foes. What may have seemed fanciful, even impossible in 2004 when Roth published the book, in 2020 seemed strangely familiar as the book became a popular television mini-series.

Similarly, Russia, which features prominently in Occupied, has long been a source of fascination and dread for western pop culture. Although Russia today is not the Soviet colossus of yore, it is led by a former KGB officer who has grown into the world's leading strongman with even more powerful China increasingly in concert with it. ${ }^{79}$ Russia's military aggression against its former Soviet Republics is well documented, as is its interference in the 2016 US Presidential elections and again its 2020 hack of sensitive US targets in the public and private sector. ${ }^{80}$ So, the affective mood music or the score as Badiou might put it, fits.

Occupied, like The Plot Against America and 2036, speaks to a feeling of unease in the global village. It premiered in Norway in 2015 and came to Netflix quickly in a variety of other media markets including the US, Canada, and the EU. It imagines the complex form of psychological warfare which might be a part of a high-tech invasion by one advanced country of another today. The series depicts a fictionalized, but surprisingly believable, scenario in which a slow-moving Russian takeover of Norwegian oil platforms and eventually the country itself is (almost) credibly presented as something other than an actual military invasion. This has of course not occurred, nor is it likely to occur in the exact terms and form depicted in the television thriller. However, the story has a chilling believability to it that only the best speculative fiction has. Viewers in Estonia, Georgia, and the Ukraine might even find the show more real than not. ${ }^{81}$ The affective environment created by Jo Nesbø and director Erik Skjoldbjærg in Occupied, as well as the world of counterfactuals imagined by it, speak to the media ecology of the present moment in the life of the global village. It also speaks to a ripening nervousness about the durability of international legal order, neoliberalism, and Technopoly. 2036 speaks to a similar anxiety insofar as it explores a possible military struggle involving the major powers in the near future.

Resonant counterfactual or speculative fiction, addresses the Rule of Law laterally in terms of its crisis. Erik Larson's book, In the Garden of the Beasts, ${ }^{82}$ mines the archives of the US State Department, the US Embassy in Berlin and other historical sources for raw material depicting the nature of the relationship between the western diplomatic core and Hitler's government before allied diplomats were expelled in anticipation of war. The book's central character is America's last interwar Ambassador, William Dodd. Although the book reads like a novel, a historical thriller to be precise, the events depicted therein, inclusive of much of the dialogue between the characters, is exhaustively sourced in the

\footnotetext{
Roth, Footnote 71 above at 64.

(Ambrosio 2017).

(Sanger et al. 2021).

(Roy 2014; Emmert 2009).

Larson, Footnote 73 above.
} 
notes. What Larson is able to evoke in the book, which is neither a historical "novel", nor historical account in the academic sense, but instead both and more, is the sense of foreboding which fell over Berlin in the years between 1933 and 1939 as Hitler consolidated his power.

The sense evoked In the Garden of the Beasts, that something terrible is taking shape in plain sight is present on every page as norms of civil society and civil conduct in Berlin are being violated brazenly and at a quickening pace in the thirties. So quick in fact, that the characters cannot process or fully interpret what is happening. Partially because of their own biases and cultural blind spots, but also because enormous breaks with the Rule of Law predictably trigger cognitive dissonance. The affective resonance with the present moment is persistent. While Larson captures a prewar feeling in Hitler's Berlin that it is enough to knock one off balance, there is a similar feeling when one sees the President of the United States embrace dictators and urge citizens to drink bleach to combat symptoms of Covid19. Of course, Badiou is right, the 1930s and the 2010s were not the same epoch and it is dangerous to conflate them too easily. But the similar feeling of foreboding and disorientation is worth considering.

\subsubsection{Valuing Speculation}

Recall that in Technopoly, Postman looks to speculative science fiction of the thirties, particularly Aldous Huxley's Brave New World as a herald of the transition from earlier forms of Technocracy to an emergent age of Technopoly. In the same spirit, we considered how Roth and Larson's accounts of America's interaction with Nazi Germany, both as a reflection of historical fact and as fictionalized alternative history, might speak affectively to the present moment. Beyond intricate tropes on authoritarianism and the Rule of Law in the world of culture, particularly in the historical literature treating the rise of fascism in the thirties, there is also a robust post-apocalyptic world of literature, film, and television treating pandemic viruses, contagion, and transmission of disease. This literature, perhaps alarmingly for those predisposed to look to more conventional sources of authority, foreshadows the current global health crisis as much as it does further and emerging threats to the conceptual space of the global village at the present stage of Technopoly.

Two novels published in the pregnant months and years before the world had heard of Covid19 are apposite, Lawrence Wright's The End of October ${ }^{83}$ and Emily St. John Mandel's Station Eleven ${ }^{84}$ exemplify the genre of the contemporary pandemic fiction. Both depict viruses which cause global contagion. Both absorb widely available media and popular science reporting on epidemiology, virology, and public health to craft a believable narrative about globalization, human survival, and the Anthropocene. Not only are these works of literature prescient, their treatment of the link between viruses and the Rule of Law tell us something about the stage of Technopoly in which available information overwhelms human discernment capacities.

Popular media and cultural treatment of the risk of pandemic outbreak was a part of our collective imagination for most of this century. Since at least the 2003 SARS outbreak and most recently the 2013 Ebola virus outbreak in West Africa, there have been constant reminders of the threat. Like the threat to the Rule of Law which was a part of the cultural zeitgeist well prior to the Trump years, the threat to public health presented by pandemic disease, including specifically zoological viruses which can cross the threshold between species, was widely foreseen in popular and scientific literature treating the subject. ${ }^{85}$ There can therefore be no doubt that this information was accessible to policy-makers, journalists, and the reading public prior the spring of 2020. ${ }^{86}$ Novels, like The End of October and Station Eleven, but also popular television shows and graphic novels such as The Walking Dead

(Mandel 2014).

84 (Wright 2020). Wright has since published an authoritative utterly non-fictional journalistic account of the first year of the Covid19 pandemic (Wright 2021).

85 See Footnote 15 above on popular science reporting on likelihood of pandemic disease and preparedness required.

86 Ibid. 
series also take up the leitmotif of viruses. In the mid twentieth century, Albert Camus wrote The Plague, 87 that book provides an archetype for the genre. Still centuries earlier, at the opening of modernity itself in 1665, Daniel Defoe's, A Journal of the Plague Year, ${ }^{88}$ inaugurated the genre. Plagues and contagions can defeat the physical and political body and sometimes neither science nor law can respond with sufficient speed to protect their domain. Fiction is the source of this insight.

\subsubsection{In the Absence of the Rule of Law: Law and Literature as Legal Theory?}

Drawing on literary or cultural sources rather than more traditional legal ones, we might even begin to challenge doctrinal imaginings of the Rule of Law. Rather than think of the Rule of Law as a synonym for natural justice, or as an abstract legal principle of equal treatment, we might consider its expression of the dialectical tension between law and politics. In the emerging contemporary context however, the old dialectic between law and politics or legal and political rationalities and imperatives, is only one axis of analysis. ${ }^{89}$ In the context of contagion or virality, science and medicine, can become preeminent to law and politics in ways which radically disrupt the status quo. Suddenly, as in wartime, history proceeds more obviously from the material and corporeal world of being or ontology than from the ideal and de-ontological world of the formal legal norm. ${ }^{90}$ This idea of a materialist narrative of the corporeal body and the body politic, might be further developed with reference to three experimental concepts: biopolitics, ${ }^{91}$ affectivity, ${ }^{92}$ and cultism. ${ }^{93}$ Each can be demonstratively glimpsed in fictional literature treating pandemic disease and in the great crisis of the present.

\subsubsection{Biopolitics}

Foucault's nascent and posthumously theorized concept of biopolitics considers how medico-scientific rationalities which exist at the level of the health of the population or species, and ultimately ideas about the Rule of Law and regulation of human conduct understood to be legal or political, are overlapping rather than siloed. In The End of October, Wright describes pandemic disease as "more powerful than armies" and "more arbitrary than terrorism". Disease, according to Wright, is similarly "crueler than human

87 (Camus [1948] 2013).

88 (Defoe 1665).

89 For a powerful meditation on binaries and dialectical thinking, specifically of their productive, transformative and constitutive capacities see (Jameson 2009). Arguing that it is mediation itself which permits the dialectical relationship to form meaning and bear fruit: "Mediation is not only the 'black box' through which one state passes, on its mysterious metamorphosis into a radically different one. It also names the relationship itself, the very inner link of the binary opposition, the equal sign which can signify either identity or difference, or indeed both at the same time."

90 This form of "materialist" narrative analysis is inspired by the work of Peter Goodrich. Goodrich, Footnote 30 above at 27 "while law seeks to portray a system of rules that are general in nature and abstract in their orderings, this self-image omits a key aspect of so-called black letter law ... which is that even its letters are material, coloured, haptic, housed and bound or now more often flickering across a screen but nonetheless special organized, material and mattering." Or at 28 , "The very word for law derives from nome and thence nomos-from which we derive the normative or rule bound-means earth, dirt, the humus, in the human. Matter precedes law." Again at 39, "materiality precedes classification and normative iterations, however age old they may be". Making the same point while highlighting the subtlety of meaning conveyed by the written word at 44 : "The letters of the law arrive already marked matterphorically and metaphorically."

91 The coinage is traceable Foucault's 17 March 1976 Lecture at the College to France, entitled "Society Must Be Defended". These essays along with other seminal works on biopolitics are usefully published together in (Campbell and Sitze 2013). For a contemporary reading of biopolitics, see (Negri 2008; Hardt and Negri 2009).

92 A note about terminology, the English language translators of Gilles Deleuze and Felix Guatarri's A Thousand Plateaus explain that their usage of the term "affect" or "affectation" is translated from the French "l'affect" as much as the more ancient usage in Spinoza which Deleuze and Guatarri call term "affectus". Together, the concept of affectivity is described by Brian Massumi, Deleuze and Guatarri's editor and translators as, "[A]n ability to affect and be affected. It is a personal intensity corresponding to the passage from one experiential state of the body to another and implying and augmentation or diminution of that body's capacity to act. L'affection (Spinoza's affection) is each such state considered as an encounter between the affected body and a second, affecting, body (with body taken in its broadest possible sense to include 'mental' or ideal bodies)." In terms of affective politics or "governance by tweet", see Delage, C., Goodrich, P., Wan, W. Footnote 54 above at 9-10 on the collapsing line between law and politics. Contra Marshall McLuhan's the medium is the message "the messenger is the message, the medium is the law ..." At 14: Now we "circumvent the traditional criteria of truth in discourse in favour of impact and effect, circulation and adhesion ... "

93 See generally in a sociological register (Webber [1922] 1958). In the contemporary psychological register treating the Trump presidency, see (Hassan 2019). 
imagination." ${ }^{\prime 94}$ The result is to place medical, scientific, and public health rationalities on equal, or often superior, footing with both political and legal considerations which are normally understood to be balanced by the Rule of Law. The imperative of disease or contagion treats the collective population, rather than the individual citizen as the superior rights holder. To some extent neoliberalism and Technocracy do the same thing with their crude market-based utilitarianism. Public health rationalities and pleas to communal wellbeing then predictably attract the support of progressives and the distain of traditionalists, individualists, and self-described libertarians. We have seen this in the context of the policy environment surrounding the Covid19 pandemic. The cultural politics of mask wearing as much as vaccine hesitancy and conspiracy theories about the vaccines may be a hideous reflection of contemporary biopolitics.

\subsubsection{Affectivity: What Fear of Contagion Feels Like}

Speaking to the biopolitical imperative of the health of the species over the rights of the individual which prevail in normal times in a liberal society, Camus writes, "no one will ever be free so long as there are pestilences." ${ }^{\prime 95}$ Also in The Plague, he describes how the law, legality, and regulation are required to combat pandemic disease through coordinated action but that public officials are invariably reluctant to take draconian measures for fear of panicking the populace. Similarly, Camus evokes how pandemic disease, especially when air-born and respired, can terrorize the human species by interfering with mammalian sociality, humanity, and compassion. In other words, our affective qualities. As anyone suffering through the current pandemic will know, even for those lucky enough to avoid getting ill, an equally powerful enemy in the form of fear, isolation, and madness looms over everything: "And while a good many people adapted themselves to confinement and carried on their humdrum lives as before, there were others who rebelled and whose one idea now was to break loose from the prison-house." 96

Literature, particularly well-considered and researched speculative fiction about dystopic but plausible futures, taps powerfully into feelings of dread and anxiety. Andrew Maynard, a Professor in the School for the Future of Innovation in Society at Arizona State University, writes in a short book, Future Rising, which is, among other things, a testament to the importance of science fiction literature and art to the imagining of what is possible, particularly how we respond collectively to a rational fear of a dystopian future of worsening pandemics, climate change and war:

Living in the modern world, we have a vast array of personal, social, and technological ways in which we can fight fear, avoid it, or simply make it disappear. Yet at the heart of all of them is our ability to foresee and to viscerally imagine the consequences of futures that we would rather avoid. ${ }^{97}$

This may in fact be the only defense viable against advanced Technopoly. Speaking to the research of Cambridge physicist Brian Pippard in the eighties, Maynard writes, "Pippard was fascinated by transitions between present and future that were abrupt and irreversible-transitions that occur at a tipping point beyond which everything changes and there is no going back, such as the snapping of a branch, or the breaking of a wave." ${ }^{\prime 8}$ Literature, often in the genres of speculative futurism or alternative historicism, permits us to anticipate certain future possibilities by seeing them as latent tendencies in the present. A rich vein of literature exists which addresses the social, technological, and even spiritual elements of pandemic disease. Laterally, that literature is also attentive to how a pandemic or climate disaster can reshape political discourse, public policy, and legal authority (and therefore also what is understood by the Rule of Law).

\footnotetext{
Wright, Footnote 84 above at 22.

Camus Footnote 87 above at 37.

(Ibid., p. 100).

(Maynard 2020, pp. 99-100).

(Ibid., p. 173).
} 


\subsubsection{Mass Cultism}

Well prior to the global health pandemic which descended on the world in the spring of 2020, the Rule of Law was in crisis. Events like Brexit and the presidency of Donald Trump were only the most notable iterations of this crisis, coming as they did from the west's two oldest liberal democracies. Even so, the focus of Rule of Law scholars and commentators in English-speaking Common Law jurisdictions had not been on the question of civil society, the social contract and the state's integrity, but rather on the more foundational question of the cult of the personality seeming to surround Mr. Trump himself.

If the Rule of Law has a specific role to play in the present public health crisis, it is one which may not fit neatly within our recent experience. It is for this reason that we might draw on literature, television, and film, to think about twenty-first century threats to the social order, such as it is. Emily St. John Mandel's Station Eleven is a novel-length rumination of what things might look like if a pandemic were to be so lethal that technological society disappeared entirely and left the earth a truly postapocalyptic landscape. In the void which is the absence of the Rule of Law or an agreed upon social contract, one of the things which invariably thrives in these fictional accounts is cultism.

Mandel develops a minor character called "the Prophet" whose appeal is that he reimagines the fictional pandemic virus as the work of an avenging God sent to purge the weak from the earth. The Prophet links the book's fictional "Georgia Flu" to the failure of technocrats to take seriously earlier, and less lethal and less contagious epidemics (consider how despite recent experience with SARS, MERS and Ebola in different jurisdictions, technocrats at the helms of state and international bureaucracies were purportedly caught off guard by the virulence and rapidity of the spread of Covid19). ${ }^{99}$ The religious and apocryphal resonances in Mandel's prophet who roams the post-pandemic world as it attempts to rebuild itself and come to terms with the breadth of its loss, are important. While the lethality of the fictional virus in Station Eleven, as much as the imagined influenza in The End of October, is far deadlier than Covid19, the book published six years before the existence of Covid19 became known, seems to grasp the way in which viruses can sneak up and obliterate lives and worlds. So much so that established forms of authority and truth-discourse can open the door to false prophets. Hassan makes a similar argument from a psychologist's perspective of Trump's America. ${ }^{100}$

Mandel's post-pandemic world is one in which the Rule of Law is long gone and, in its place, there is a traumatic wound, but also an as yet unrealized possibility of something new. The same is true of Wright and Camus' whose fictional world of pandemic disease resemble each other in this way. Each offers glimpses of the new forms of cooperation, solidarity and human kindness which can exist, even alongside widespread sickness and death.

If the Rule of Law is based on reason and principle, neither of which are cognizable to a virus, whether that virus be in the form of a biological contagion or misinformation about matters of public importance, any rational discourses, can reach a limit point.

\subsection{Re-Examining the Rule of Law for the 21st Century Media Ecosystem}

In the US, Congressional oversight of the President and the President's power to appoint Supreme Court judges are among the key touchstones of the Rule of Law as reflected in the constitutional architecture itself. In Canada, the Supreme Court has recognized the principles of constitutionalism and the Rule of Law as unwritten principles nevertheless at the heart of Canada's legal order. ${ }^{101}$ The difficulty posed by the present moment goes beyond the stress the Trump presidency placed on American legal and political institutions. Public health policy imperatives and scientific rationality require attention to a

99 In the US, it is well reported that the Trump administration shuttered the Obama administration pandemic preparedness operation (Cameron 2020; Tracy 2020; Obama Team 2020). On general lack of preparedness and foreseeability of a Covid-like pandemic in the years before the pandemic see (Young 2018). Then in March of 2020 (Frankel 2020).

100 See S. Hasan Footnote 93 above.

101 Reference re Secession of Quebec, [1998] 2 SCR 217, paras 70-78. 
different set of concerns than those which can be easily segmented into the law / politics binary taken for granted by the Rule of Law and normally attendant to judicial review, legislative oversight, and parliamentary style debate. ${ }^{102}$ Today, the problems of authority, rationality, and truth are themselves stumbling blocks for public discourse. Again, this is characteristic of Technopoly and it is well expressed in speculative futurism and alternative historical literature. It can also be further illuminated using the concepts of biopolitics, ${ }^{103}$ affectivity, ${ }^{104}$ and mass cultism. ${ }^{105}$ Each is glimpsed in the contemporary fictional literature treating pandemic plagues as their subject matter. Each speaks to a call to the material realities of the body and the planet which can be lost in the day-to-day existence of our contemporary media ecosystem in which facts and conspiracy, evidence-based argument, and infantile contrarianism, vie for authority. Each concept then unpacks briefly why the distinction between law and politics and the law bound quality of the Rule of Law is wobbly in Technocracy.

1.3.1. Biopolitics: Thinking about Our Central Nervous Systems, Bodies, and Minds as Components of Collective Subjectivity

The question of biopolitics, most nascently articulated in Foucault, is more widely expressed in cultural forms such as literature and television than we generally acknowledge. Particularly the genres of science fiction and the subgenre of post-apocalyptic speculative science fiction in particular. Biopolitics treats the collective body of the polity as the subject of governance but also as a source of potential liberation and therefore of revolutionary power. Foucault stated it thus, "in question is no longer the juridical existence of sovereignty; at stake is the biological existence of the population."106 The Rule of Law is about the juridical existence of sovereignty. But climate change and pandemic disease are about the biological health of the population and the planet. The fictional literature on virus and plagues presents this theme well. Biopolitics helps to think through how our bodies, both in their vulnerable physical and corporeal forms, as well as their affective and communal capacities, exist in the present moment. These concepts can be fruitfully brought into conversation with the idea of an electronic media environment which passes through the central nervous system of so many and constitutes the global village today. This is particularly true in Technopoly, where the social body's immune system controls and deals with information in a manner analogous to the body's immune system. Ultimately, this is the potential link between biopolitics and what Postman understands as information glut or information overload in Technopoly:

The dangers of information on the loose may be understood by the analogy ... An immune system, in short, destroys unwanted cells. All societies have institutions and techniques that function as does a biological immune system. Their purpose is to maintain the balance between the old and the new, between novelty and tradition, between meaning and conceptual disorder, and they do so by 'destroying' unwanted information. ${ }^{107}$

In the contemporary epoch, our bodies and minds are constantly shaped by information technology in such a way to change us at the level of species being. ${ }^{108}$ Moreover, our institutions are failing in what Postman describes as their role as a functioning immune system for the social body. Contemporary science fiction and fantasy is replete with cyborgs,

\footnotetext{
102 See Jamieson Footnote 89 above.

103 See generally Footnote 91 above re biopolitics.

104 See e.g., governance by Delage, Tweet C., Goodrich, P., Wan, M., et al., Footnote 54 above at 9-10 on the collapsing line between law and politics. See Contra Marshall McLuhan's the medium is the message "the messenger is the message, the medium is the law ... " At 14: Now we "circumvent the traditional criteria of truth in discourse in favour of impact and effect, circulation and adhesion ..."

105 For a study of the Trump Presidency as mass cultism see Steven Hassan Footnote 93 above.

106 (Foucault 1984). Biopolitics Footnote 91 at 43.

107 Postman Footnote 2 above at 72-73

108 Few make this case more powerfully or comprehensively than historian Yuval Harrari in the follow up to his 2014 magnum opus, Sapiens, see Footnote 21 above. Then see (Harari 2015).
} 
hybrids, and other imaginative (re)iterations of our real contemporary condition. However, it is also filled with alternative histories of unlived twentieth centuries and speculative forward-looking imaginings of the near or immediate future.

The best science fiction writers foresee much about the future which present policymakers are loathe to acknowledge. When Chief Justice Wagner of the Supreme Court of Canada, speaking for a unanimous bench, recently recognized climate change as a "existential threat to human life in Canada and around the world", ${ }^{109}$ he strongly implies that the Rule of Law can only be meaningfully interpolated as a concept in the twenty-first century if it can be understood to demand conformity with the need to preserve the planet and its biome as a collective habitat for our species. This is a potentially strong way to think about collective subjectivity and the type of political and legal, as well as technical and scientific, work which will have to be done in the very near future. The Rule of Law cannot and should not be something which exists outside the imperatives of planetary health, even beyond that of our species alone.

Wisely presuming today's problems as intensified in the future, speculative futurists like Kim Stanley Robinson, offer something of value to our comprehension of the way in which politics now affects biological life. Certainly, the life of the planet generally but also our individual and collective bodies through science and medicine. Robinson's most recent novel, The Ministry of the Future, ${ }^{110}$ provides a more idealist than realist, glimpse of a world in which human beings attempt collectively to de-carbonize and radically change the economic mode of production and culture to permit human survival on the planet. He does so, convincingly or not, by doubling down on the idea of the Rule of Law and the possibility of a new social contract.

The Ministry of the Future is a fictional UN ministry founded to protect and promote the interest of future, as yet unborn generations and the natural world which they will inherit. The book's protagonist, Mary, the putative Minister of the Future, finds herself in constant conflict with the heads of national central banks who do not want to give up their levers of power to permit the liberation of sufficient capital to undertake the steps necessary to arrest extinction level warming. In the world of the book, the Rule of Law has been pushed well beyond its current crisis by principled environmentalists or ecoterrorists who have turned in desperation to launching attacks against polluting industries, governments, and infrastructures. In an illustrative passage, Mary is confronted by a radical anti-carbon activist and she resists his call to revolutionary violence: "'Violence begets violence,' Mary said. 'It cycles forever. So here we are.'” Undeterred, he retorts, "'[b]ut look, the violence of carbon burning kills many more people than punishment for capital crimes ever would. So really your morality is just a kind of surrender.'" In response, "she [Mary] shrugged, 'I believe in the rule of law ... " Undeterred, the riposte from the radical activist is the classic natural law crie de Coeur, "'[w] hich would be fine, if the laws were just. But in fact, they're allowing the very violence you're so opposed to!'” And in return, a reformist response from the heroine, " $\mathrm{t}$ ]hen we have to change the laws.'" The discussion goes on in a similar way and reaches into the question of whether "violence against the carbon burning itself" or bombing a coal plant "might not be morally, if not legally defensible." The answer for Mary is always the same: "We work within the law. I think that gives us a better chance of changing things.'" Weary in the end, she concedes "'A lot of our work these days goes to trying to point out the problems created by the currently existing legal regime, and recommending corrections ... it's a process."'111 Incrementalism, pragmatism and liberal reformism. It doesn't feel sufficiently radical or adequate to the moment. But Robinson seems to suggest that there are no other options worthy of consideration. The book leaves the reader sympathetic with Mary but doubtful that the Rule of Law can work fast enough to solve a rapidly moving factual problem at the planetary level. 
There is a reason the recurring debate between the character of Mary and her interlocutor is circular and leads nowhere. It is part of the problem. Literature can demonstrate this in a way which speaks to a more profound question. Our technocratic and rationalistic modes of addressing and dealing with crisis and threats are often too slow and cumbersome in real time. Or, we are simply overcome by the data, paralyzed by false debate, and unable to act. This was foreseen by Postman in terms of information glut. It is also an increasingly non-controversial and well-established point, even in mainstream neoliberal and centrist circles in the US, that a significant portion of the public has had their brains short-circuited by Trumpism and the form of political propaganda and manipulative mis and disinformation to which it corresponds. ${ }^{112}$

\subsubsection{Affectivity (Over Rationality?)}

The question of biopolitics is closely related to the decentralization of rationality from our political world and therefore to some extent from the obviousness of what might be understood by the Rule of Law. Rationality, as in rational politics, but also legal rationality and ultimately scientific rationality, underpins our imagining of the technocratic state of modernity in the stage prior to Technopoly which Postman called Technocracy. In postmodernity as expressed in what Postman calls Technopoly, this remains our status insofar as we regard the present as contiguous with a modern tradition which has grown to venerate empirical observation, logical inference and scientific process above all. However, pure rationality is not (if it ever was) what truly explains our imagination of politics or law today. Particularly in the context of an electronic environment in which artificial intelligence in the form of complex and interactive algorithms mediate forms of speech and communication at the global scale well beyond what McLuhan glimpsed in the possibility of a global village. Here, at the outer limits of Technopoly in late modernity, we might ironically return to our status as premodern beings governed by feelings and instinct more than rational argument or executive function. At present, our affective environment is no longer created by the natural world, it is created by our electronic media environment and channeled through our limbic system, this is what it means to speak of having a media ecology. It is also what is expressed in the affective environment of biopolitics. Here, the world of literature and television are important reservoirs of fantasy, escapism, and reflexive imagination which are adjacent to, and overlapping with, the media ecosystem.

To understand the present globalized media ecology and the affective environment it elicits, we can look to the world's current roster of authoritarian leaders like Donald Trump and Jair Bolsanoro, both of whom brazenly flaunted the Rule of Law in their rise to power. In the thirties, as depicted both historically in books like Larson's In the Garden of the Beasts or more fictionally in Roth's The Plot Against America, the politics of the present age are manifest. In both books, a cult of the personality at the national scale is documented. The irrational and sometimes anti-science and anti-expertise impulse of this type of leadership cult is showcased. In both books, the Rule of Law collapses utterly in the face of a populace under the profoundly irrational spell of a charismatic authoritarian leader. Similarly, the speculative literature on pandemic disease unpacks some of the implications of fully or partially shutting down the state, the economy and the communications infrastructure which links the global village. Both are key themes in Mandel's Station Eleven and Wright's The End of October.

\subsubsection{Cult of the Personality over Impersonal Rule}

Steven Hassan, a psychologist who specializes in cult recruitment and mind control is the author of The Cult of Trump. ${ }^{113}$ In it, Hassan argues that Trump's base supporters as well as much of the rank and file of the national and state Republican Parties inclusive of legislators themselves, are now the thrall of Trump as a sort of living deity or false 
prophet. Hassan argues that Trump has built a rapport with his followers which differs from the usual one built between American Presidents and voters. He also demonstrates multifaceted and overwhelming similarities between Trump's hardcore base and death cults in recent American history. Similarly, the speculative science fiction treating plagues often compellingly imagines the pandemic as a boon to cults and cult leaders. Particularly those seeking to capitalize on fear and anxiety about the future.

A recurrent feature of science fiction literature is the figure of the charismatic or cult leader, this type of leader often emerges in the midst of a plague or some other cataclysmic event. In more ecological science fiction, that figure is sometimes subordinated to a more powerful imagining of the natural world. Margaret Atwood's MaddAddam trilogy ${ }^{114}$ explores this dynamic in multiple ways at the limits of a world destroyed by science, capitalism, and patriarchy in one swallow. Yet, the cult leader in this genre is usually only temporarily powerful, a bit player compared to larger more malevolent structural and ideological currents lurking beneath the surface. In another popular ecological science fiction series, Jeff VanderMeer's Southern Reach trilogy, ${ }^{115}$ an imaginative alternate universe is invented as a means of dealing with the unknown without the need for a leader or a strongman.

\section{Conclusions}

Understanding law as regulation or as legislation which has a governance outcome for media and communications technologies or industries is an inquiry into substantive law and policy. That type of legal research has a central place in the literature on media law and the interdisciplinary research in law and communications. Adjacent to that, we sought to consider how our contemporary media environment might contribute to new forms of being and new forms of reality hitherto only weakly grasped by jurists. An aspect of this is the failure of the Rule of Law to resist authoritarianism; the failure of public health authorities to predict and manage the Covid19 pandemic early on; and the ongoing failure of political leaders and global elites to treat climate change with sufficient seriousness or discipline. A few other major global problems, including rising tension between the globe's great powers and the vulnerability of our collective Internet and electronic infrastructure to malevolent militarized hacking should probably also make the list. Other examples abound.

To theorize Technopoly and what it might have to say about the present day to lawyers and policy-makers, we sought to mobilize a conceptual rubric capable of describing the moment. The methodology utilized was self-consciously iconoclastic because rather than looking to literature and popular culture as diversion, it treated them as primary sources of authority. Going forward, we might think of popular culture, as a potential antidote to information glut. In so doing, we might also learn how to speak without alarmism about what is an objectively alarming present. We might also learn to think and write in a way which lays the groundwork for conceptual reinvention and a renewed legal project dedicated to mobilizing more of the considerable intellectual resources at the disposal of our species. To begin down this road it might be helpful to think about the present moment in history as high Technopoly and to situate our understanding of this period alongside more established or familiar concepts like the Rule of Law.

Funding: This research received no external funding.

Institutional Review Board Statement: Not applicable.

Informed Consent Statement: Not applicable.

Data Availability Statement: Not applicable.

114 (Atwood 2003, 2009, 2013).

115 (VanderMeer 2014a, 2014b, 2014c). 
Acknowledgments: Thank you to the anonymous reviewers and special guest editors. I am particularly indebted to Pascale Chapdelaine whose engagement, support and feedback immeasurably improved this paper.

Conflicts of Interest: The author declares no conflict of interest.

\section{References}

Ackerman, Elliot, and Admiral James Stavridis. 2021. 2034: A Novel of the Next World War. New York: Penguin Press.

Allen, Marshall, and Meg Marco. 2020. How Your Brain Tricks You into Taking Risks during the Pandemic. Pro Publica. November 2. Available online: https://www.propublica.org/article/how-your-brain-tricks-you-into-taking-risks-during-the-pandemic (accessed on 7 June 2021).

Ambrosio, Thomas. 2017. The Architecture of Alignment: The Russia-China Relationship and International Agreements. Europe Asia Studies 69: 110. [CrossRef]

Andrew, Jane, and Max Baker. 2021. The General Data Protection Regulation in the Age of Surveillance Capitalism. Journal of Business Ethics 168: 565. [CrossRef]

Atwood, Margarete. 2003. Oryx \& Crake. Toronto: Vintage.

Atwood, M. 2009. The Year of the Flood. Toronto: Vintage.

Atwood, M. 2013. MaddAddam. Toronto: Vintage.

Badiou, Alain. 2019. Trump. London: Polity, p. 13.

Baker, Peter. 2017. For Trump, a Year of Reinventing the Presidency. New York Times. December 31. Available online: nytimes.com (accessed on 8 April 2021).

Bingham, Tom. 2011. The Rule of Law. London: Penguin. First published 2010.

Blaire, Ann. 2011. Information Overload's 2300-Year-Old History. Harvard Business Review. Available online: https://hbr.org/2011/03/ information-overloads-2300-yea.html (accessed on 12 August 2021).

Borrows, John. 2010. Canada's Indigenous Constitution. Toronto: University of Toronto Press.

Brown, M. Neil, Justin Rex, and David L. Herrera. 2011. The Potential Tension between a Free Marketplace of Ideas and the Fundamental Purpose of Free Speech. Akron Journal of Constitutional Law E Policy 3: 55.

Bussey, Ever, and Noah Buyon. 2021. Freedom in the World in 2021: Democracy Under Siege. Available online: https:/ freedomhouse. org/sites/default/files/2021-02/FIW2021_World_02252021_FINAL-web-upload.pdf (accessed on 8 April 2021).

Cameron, Beth. 2020. I Ran the WH Pandemic Office Trump Closed It. Washington Post. May 15. Available online: https: / / www.washingtonpost.com/outlook/nsc-pandemic-office-trump-closed/2020/03/13/a70de09c-6491-11ea-acca80c22bbee96f_story.html (accessed on 8 April 2021).

Campbell, T., and A. Sitze, eds. 2013. Biopolitics: A Reader. Durham: Duke University Press.

Camus, Albert. 2013. The Plague. Edited by T. Judt. Translated by R. Buss. New York: Penguin Classics. First published 1948.

Cover, Robert. 1986. Violence and the Word. Yale Law Journal 95: 1601. [CrossRef]

Debord, Guy. 2010. Society of the Spectacle. Translated by Black and Red. Oakland: AK Press. First published 1967.

Defoe, Daniel. 1665. A Journal of the Plague Year. Available online: https://www.gutenberg.org/files/376/376-h/376-h.htm (accessed on 8 April 2021).

Delage, Christian, Peter Goodrich, and Marco Wan. 2019. Law and New Media. Edinburgh: Edinburgh University Press.

Deleuze, Gilles, and Felix Guattari. 2003. What Is Philosophy. Translated by G. Burchell, and H. Tomlinson. London: Verso. First published 1991.

Diamond, Jared. 1999. Guns, Germs \& Steel. New York: W.W. Norton. First published 1997.

Driesen, David M. 2019. President Trump's Executive Orders and the Rule of Law. Universtiy of Missouri Kansas City Law Review 87: 489.

Durnová, Anna. 2019. 425 in Post-Factual Politics. Northampton: Edward Elger.

Emmert, Frank. 2009. Rule of Law in Central and Eastern Europe. Fordham International Law Journal 32: 551.

Finnis, John. 2011. Natural Law \& Natural Rights. Oxford: Oxford University Press. First published 1980.

Florea, Dumitrita, and Narcisa Gales. 2020. After Brexit. Brief Review of the Effects of Brexit. European Journal of Law E Public Administration 7: 116.

Foucault, Michel. 1984. Right of Death and Power over Life. Durham: Duke University Press.

Frankel, Jeffrey. 2020. Coronavirus Should Not Have Caught Leaders \& Markets Off-Guard. The Guardian. March 31. Available online: https: / www.theguardian.com/business/2020/mar/31/coronavirus-should-not-have-caught-leaders-and-marketsoff-guard (accessed on 12 August 2021).

Friedmann, Danny. 2015. Trademarks and Social Media: Towards Algorithmic Justice. Northampton: Edward Elgar Pub. Ltd.

Fukuyama, Francis. 2006. The End of History and The Last Man. New York: Free Press. First published 1992.

Gillespie, Sally. 2019. Climate Crisis and World Consciousness. Oxford: Taylor and Francis.

Goodrich, P. 2021. Law \& Literature. Cheltenham: Elgar.

Goodrich, Peter, and M. Valverde. 2005. Nietzsche E Legal Theory. New York: Routledge.

Gross, Bertram. 1964. The Managing of Organizations: Administrative Struggle. Glencoe: Free Press of Glencoe, vols. I-II.

Harari, Yuval Noah. 2015. Homo Deus. New York: Signal.

Hardt, M., and A. Negri. 2009. Commonwealth. Cambridge: Harvard Belknap Press, pp. 46, 58. 
Harrari, Yuval N. 2014. Sapiens. New York: Random House.

Hassan, Steven. 2019. The Cult of Trump. New York: Free Press.

Honigsbaum, Mark. 2019. The Pandemic Century. New York: Norton.

Horrigan, John. 2016. Information Overload. Pew Research Center. Available online: https://www.pewresearch.org/internet/2016/1 2/07/information-overload/ (accessed on 7 April 2021).

Hutchinson, Allan C. 2005. Evolution and the Common Law. Cambridge: Cambridge University Press.

Jacoby, Susan. 2009. The Age of American Unreason. New York: Vintage.

Jameson, Fredric. 2009. Valences of the Dialectic. London: Verso.

Javanbakht, Arash, and Christian Capotescu. 2020. Lethargic Global Response to Covid19: How the Human Brain's Failure to Assess Abstract Threats Cost Us Dearly. The Conversation. April 27. Available online: https://theconversation.com/lethargic-globalresponse-to-covid-19-how-the-human-brains-failure-to-assess-abstract-threats-cost-us-dearly-137119 (accessed on 30 March 2021).

Kertesz, Agnes. 2016. Brexit's Legal Framework. ELTE Law Journal 1: 93.

Klingberg, Torkel. 2009. The Overflowing Brain: Information Overload and the Limits of Working Memory. Oxford: Oxford University Press.

Kristensen, Hans, and Matt Korda. 2020. Status of World Nuclear Forces. Federation of American Scientists. Available online: https:/ / fas.org/issues/nuclear-weapons/status-world-nuclear-forces/ (accessed on 11 April 2021).

Kunreuther, Howard, and Paul Slovic. 2021. Learning from the Covid-19 Pandemic to Address Climate Change. Management $\mathcal{E}$ Business Review 1: 92-99. Available online: https://mbrjournal.com/wp-content/uploads/2020/11/18_Learning-from-thePandemic-to-Address-Climate-Change.pdf (accessed on 11 April 2021).

Larson, E. 2011. In the Garden of the Beasts. New York: Random House.

Larson, Eric J. 2021. The Myth of Artificial Intelligence. Cambridge: Harvard Belknap Press.

Lincoln, Anthony. 2011. FYI: TMI: Toward a Holistic Social Theory of Information Overload. First Monday 16: 3-7. [CrossRef]

Lipschultz, Jeremy Harris. 2015. Social Media Communication: Concepts, Practices, Data, Law and Ethics. Oxfordshire: Routledge.

Mandel, Emily St. John. 2014. Station Eleven. Toronto: Harper Perennial.

Maynard, Andrew. 2020. Future Rising. Coral Gables: Mango Publishing.

McLuhan, M. 2011. The Gutenberg Galaxy: The Making of Typographic Man. Toronto: University of Toronto Press. First published 1962.

McLuhan, M. 1970. Culture Is Our Business. New York: Ballentine Books.

Meyers, J. B. 2008. Re-Envisioning Sovereignty: The End of Westphalia. In Australian Yearbook of International Law. Edited by T. Jacobsen, C. Sampford and R. Thakur. Farnham: Ashgate, vol. 27, pp. 281-93.

Meyers, J. B. 2010. Rethinking Constitutional Design and the Integration/Accommodation Binary. Modern Law Review 73: 656-78. [CrossRef]

Meyers, J. B. 2020. Nietzsche and the Law of "the Other": The Jew in Refraction. International Comparative, Policy E Ethics Law Review 2: 297-336.

Meyers, J. B. 2021. What We Talk About When We Talk About the Rule of Law. Canadian Journal of Comparative E Contemporary Law 7: 405.

Napoli, Philip M. 2018. What if more speech is no longer the solution? First Amendment Theory Meets Fake News \& the Filter Bubble. Federal Communications Law Journal 70: 55.

Negri, Antonio. 1999. Insurgencies. Translated by M. Boscagli. Minneapolis: University of Minnesota Press. First published 1992.

Negri, A. 2008. The Porcelain Workshop. Los Angeles: Semiotext(e), pp. 164-65.

Nichols, Tom. 2018. The Death of Expertise. Oxford: Oxford University Press.

Nietzsche, Friedrich. 1977. The Portable Nietzsche. Translated by Walter Kaufmann. London: Penguin Books.

Nietzsche, F. 1892. Part III, Aphorism 12, “On Old and New Tablets”. In Thus Spoke Zarathustra. Edited by Adrian Del Caro and Robert Pippen. Translated by Adrian Del Caro. Cambridge: Cambridge University Press, Available online: http://users.clas.ufl.edu/ burt/LoserLit/zarathustra.pdf (accessed on 12 August 2021).

Nussbaum, Marth. 2000. Sex E Social Justice. Oxford: Oxford University Press.

Obama Team. 2020. Obama Team Left Pandemic Playbook for Trump Administration Officials. PBS News. May 15. Available online: https:/ / www.pbs.org/newshour/nation/obama-team-left-pandemic-playbook-for-trump-administration-officialsconfirm (accessed on 30 March 2021).

Osterholm, Michael T., and Mark Oshaker. 2017. Deadliest Enemy. New York: Little, Brown \& Co.

Postmen, N. 1992. Technopoly. New York: Random House Books, p. 69.

Quammen, David. 2012. Spillover: Animal Infections \& The Next Human Pandemic. New York: Norton.

Rauch, Jonathan. 2021. The Constitution of Knowledge. New York: Brookings Institute.

Robinson, Nicholas A. 2014. Fundamental Principles of Law for the Anthropocene. Environmental Policy E Law 44: 13.

Robinson, Kim Stanley. 2020. The Ministry of the Future. New York: Orbit Books, p. 352.

Roetzel, Peter G. 2019. Information overload in the information age: A review of literature from business administration, business psychology, and related disciplines with a bibliometric approach to framework development. Business Research 12: 479-522. [CrossRef]

Roth, P. 2004. The Plot against America. London: Penguin.

Roy, Allison. 2014. Russian 'deniable' intervention in Ukraine: How and why Russia broke the rules. International Affairs 90: $1255-97$. 
Rubenstein, David S. 2018. Taking Care of the Rule of Law. George Washington Law Review 86: 168.

Sanger, David E., Nicole Perlroth, and Eric Schmitt. 2021. The Scope of Russian Hacking Becomes Clear: Multiple U.S. Agencies Were Hit. February 9. Available online: nytimes.com (accessed on 30 March 2021).

Sha, Sonia. 2016. Pandemic. New York: Sarah Crichton Books.

Slovic, Paul. 2000. The Perception of Risk. New York: Routledge.

Slovic, Paul, and Ellen Peters. 2006. Risk Perception \& Affect. Current Directions in Psychological Science 15: 6.

Speier, Cheri, Joseph S. Valacich, and Irish Vessey. 1999. The Influence of Task Interruption on Individual Decision Making: An Information Overload Perspective. Decision Sciences 30: 337-60. [CrossRef]

Toffler, Alvin. 1971. Future Shock. Toronto: Bantam Books. First published 1970.

Tracy, Abigail. 2020. How Trump Gutted Obama's Pandemic Preparedness System. Vanity Fair. May 1. Available online: https: //www.vanityfair.com/news/2020/05/trump-obama-coronavirus-pandemic-response (accessed on 9 May 2021).

Trautman, Lawrence J. 2019. Presidential Impeachment: A Contemporary Analysis. University of Dayton Law Review 44: 529. [CrossRef]

UN. 2019a. UN Disarmament Yearbook, Part 1. New York: UN, vol. 44, pp. 2-19.

UN. 2019b. United Nations Climate Change Annual Report. New York: UN.

VanderMeer, J. 2014a. Annihilation. New York: Harper Collins.

VanderMeer, J. 2014b. Authority. New York: Harper Collins.

VanderMeer, J. 2014c. Acceptance. New York: Harper Collins.

Vattimo, Gianni. 1988. The End of Modernity. Baltimore: Johns Hopkins University Press. First published 1985.

Versteeg, Mila, and Tom Ginsburg. 2017. Measuring the Rule of Law: A Comparison of Indicators. Law E Social Inquiry $42: 100-37$.

Watson, Jack. 2015a. “You Don't Know What You've Got 'til It's Gone: The Rule of Law in Canada" (Part I). Alberta Law Review 52: 689-730. [CrossRef]

Watson, Jack. 2015b. “You Don't Know What You've Got 'til It's Gone: The Rule of Law in Canada" (Part II). Alberta Law Review 52: 949-88. [CrossRef]

Webber, Max. 1958. The Three Types of Legitimate Rule. Berkeley Publications in Society E Institutions 4: 1-11. First published 1922.

World Justice Project. 2020a. Rule of Law Index (Part I). Available online: https:/ / worldjusticeproject.org/our-work/research-anddata/wjp-rule-law-index-2020 (accessed on 30 March 2021).

World Justice Project. 2020b. Rule of Law Index (Part II). Available online: https://worldjusticeproject.org/our-work/research-anddata/wjp-rule-law-index-2020 (accessed on 30 March 2021).

Wright, Lawrence. 2020. The End of October. New York: Alfred Knopf.

Wright, Lawrence. 2021. The Plague Year. New York: Knopf.

Young, Ed. 2018. The Next Plague Is Coming. Is America Ready? The Atlantic. July/August. Available online: https:/ / www.theatlantic. com/magazine/archive/2018/07/when-the-next-plague-hits/561734/ (accessed on 12 August 2021). 